\title{
A experiência barroca e a identidade local na Semana Santa de Campanha, Minas Gerais
}

\author{
Suzel Ana Reily (Queen's University, Belfast, Irlanda do Norte) \\ s.reily@qub.ac.uk
}

Resumo: Este trabalho analisa a formação de uma sensibilidade barroca em Minas Gerais a partir da orientação participativa e altamente emotiva das festas coloniais, cujo legado se mantem presente nas festas religiosas de muitas antigas cidades mineradoras do estado. Enfocando as celebrações da Semana Santa na cidade sul-mineira de Campanha, o texto mostra como este evento anual era organizado pela Irmandade do Santíssimo Sacramento, passando então às mãos de uma comissão local após a extinção da irmandade. Se até meados do século XIX, havia músicos semi-profissionais contratados para tocar e cantar nas celebrações, a música foi assumida progressivamente por grupos de amadores. Assim, a festa passou a ser entendida como uma produção local e a cada ano a população renova o seu orgulho campanhense, ao contemplar sua capacidade de produzir um evento tão 'maravilhoso'.

Palavras-chave: barroco; Minas Gerais; Semana Santa; participação; identidade local.

\section{The Baroque Experience and Local Identity in the Holy Week of Campanha, Minas Gerais}

Abstract: This paper analyses the formation of a baroque sensibility in the State of Minas Gerais (Brazil) that derives from the participatory and highly emotive orientation of the colonial festivals, the legacy of which is still present in many former mining towns in the region. By focusing upon the Holy Week celebrations in Campanha, a small town in southern Minas Gerais, the text shows how this annual event was organized by the Confraternity of the Holy Sacrament, but was then transferred to a local committee after the confraternity was made extinct. If up to the mid 19th century there were semi-professional musicians to perform for the celebrations, responsibility for the music was slowly taken over by amateur groups. In this way the festival came to be understood as a local affair, and each year the population renews its pride in itself for its capacity to stage such a 'marvelous' event.

Keywords: baroque; Minas Gerais; Holy Week; participation; local identity.

\section{Introdução}

Entre os historiadores de arte, o barroco é visto como a resposta estética à contra-reforma. 0 protestantismo questionava o uso de imagens pela igreja, vendo-o como uma forma de idolatria. Assim, o Concílio de Trento foi convocado para debater essa questão, junto com muitas outras levantadas pelo movimento reformista. Com relação a imagens, o Concílio de Trento concluiu que elas não constituiam formas de idolatria, pois apenas representavam as figuras nelas retratadas; o devoto não estaria venerando a imagem, mas sim a personagem santa nela representada. A Igreja considerava as representações necessárias, dado o alto índice de analfabetismo entre a população cristã da época. De acordo com as autoridades eclesiásticas, o povo precisava de imagens para assimilar a doutrina católica e a Igreja só proporcionou algumas diretrizes que deveriam ser seguidas pelos artistas em suas obras para garantir sua ortodoxia.

Além de aprovar o uso de imagens para fins didáticos, os debates tridentinos também propuseram a ideia de que os seres humanos só poderiam ter acesso direto a Deus através do seu imaginário. Assim, muitos artistas começaram a ver sua arte como meio de direcionar o imaginário dos cristãos, fazendo representações da esfera divina para que os devotos pudessem ter experiências imediatas deste domínio. 0 que prevaleceu nesta busca por formas de representar o sagrado foi a estética da maravilha: isto é, uma estética de excesso, de pompa, e de grandeza - e, no século XIX, esta estética viria a ser identificada como 0 'barroco'. 0 objetivo dos artistas 'barrocos' era o de deixar os observadores maravilhados. Ao se defrontarem com a obra de arte, vivenciariam a grandeza do Reino do Céu. Deste modo, a arte teve consequências que transcenderam as pedagógicas previstas no Concilio de Trento: tornou-se uma esfera central de persuasão religiosa, justamente pelo impacto que causava sobre os observadores.

A arte barroca foi se desenvolvendo cada vez mais com o intuito de intensificar o impacto que teria sobre os sentidos dos fiéis. Tratava-se, portanto, de persuadir através da mobilizaçao da emoção, mais que da razão (STOCKSTAD, 2002, p.758). Ao contemplar a obra de arte, o devoto se integraria a ela, identificando-se com as personagens 
nela retradas; viveria, no seu imaginário, os episódios e sentimentos das figuras nela representadas. Para intensificar ainda mais esta identificação, a arte barroca foi se tornando cada vez mais uma arte participativa e teatralizada. Assim, as 'obras' - fossem elas plásticas, sonoras ou coreográficas - eram integradas a rituais coletivos, como procissões, missas, funerais e festas de padroeiros. Enfim, através das artes, criou-se uma religiosidade vivida, posto que, nos rituais religiosos, os fiéis participavam de experiências afetivas e de fortes impactos sensoriais.

\section{A cultura barroca em Minas Gerais}

$\mathrm{Na}$ tentativa de minimizar a expansão do protestantismo nas colônias ibéricas, as práticas barrocas foram encorajadas pela Igreja por toda a América Latina. 0 próprio fervor missionário se fortaleceu com a contra-reforma e este zelo também contribuiu para intensificar a disseminação da estética barroca nas colônias. A descoberta do ouro no final do século XVII em Minas Gerais disponibilizou grandes riquezas, dando um ímpeto especial à ostentação barroca. Muito ouro foi investido na construção e decoração de igrejas bem como na produção de grandes festas religiosas com pomposas procissões e cerimoniosas missas cantadas para maravilhar os fiéis.

Estes projetos tiveram, como base institucional, as irmandades, as ordens terceiras e as confrarias, que também sustentavam a vida social dos centros urbanos da colônia (BOSCHI, 1986; SALLES 2007 [1963]). Em consonância com as ideologias do Antigo Regime português, as irmandades mineiras se estruturavam de acordo com o ordenamento da sociedade mais ampla, de modo que havia irmandades de brancos, de mulatos e mestiços e de negros, tanto escravos como forros. Serviam, por assim dizer, como associações de auxílio mútuo, cuidando de seus membros tanto na vida quanto na morte - talvez especialmente na morte, posto que cabia à irmandade enterrar seus membros, dando-os um local de repouso perpétuo bem com um funeral cristão e missas em intenção de sua alma para reduzir sua passagem pelo purgatório.

Em muitos centros de mineração uma das primeiras irmandades a ser estabelecida era a Irmandade do Santíssimo Sacramento, uma irmandade de brancos, geralmente sediada na Matriz. Depois vinham as outras, primeiramente a Irmandade do Rosário dos negros, seguida de diversas outras. Conforme a população crescia e se diversificava, aumentava o número de irmandades. Geralmente cabia à Irmandade do Santíssimo assumir a produção da Semana Santa, que passou a ser vista, em muitas comunidades, como o maior evento do calendário anual.

Vários estudiosos da cultura barroca realçam a centralidade da morte na visão de mundo do século XVIII (SKRINE, 1978, p.53), uma orientação particularmente forte na sociedade colonial brasileira (REIS, 1991). A população mineira tinha até certa obsessão com a morte - ou talvez mais precisamente, com a vida após a morte - e os artistas coloniais brasileiros se esforçaram em representar este domínio sagrado. Mas ela também era dramatizada coletivamente. Com efeito, a celebração da Semana Santa, o período em que se comemora a morte e ressurreição de Jesus Cristo, viria a se tornar um evento central em muitas cidades históricas. De acordo com João José REIS (1991, p.138):

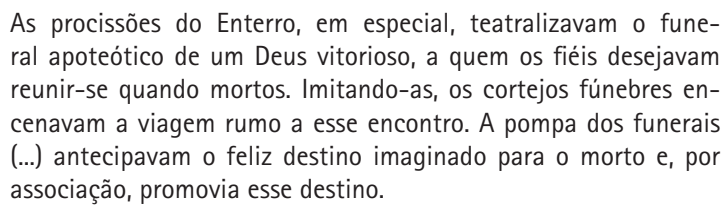

A convivência constante com a religiosidade barroca viria, então, formar uma pré-disposição por esta estética nas Minas Gerais. Utilizando a terminologia de BOURDIEU ([1972] 2002, [1979] 2007), poder-se-ia falar na formação de um 'habitus barroco', cujo legado tem se perpetuado até hoje, principalmente nos antigos centros de mineração. $A$ teatralidade das práticas barrocas, portanto, promoveram a encorporação do habitus barroco na região, definindo a religiosidade como uma experiência do universo sagrado, mas estabelecendo também a sensibilidade estética barroca como marco da identidade de Minas.

Na sua análise das irmandades de Nossa Senhora do Rosário, Célia Maia Borges (2005) chama a atenção para o papel da participação como elemento importante na integração dos escravos à irmandade e, por meio dela, à sociedade colonial mais ampla. Assim, para Borges, as irmandades negras eram mais do que um ponto de encontro para os escravos e forros: serviam como um local para a construção de um legado comum através de atividades conjuntas, re-articulando as diversas identidades étnicas ligadas às 'nações' africanas em torno de um sentimento coletivo de raça. E vale notar que a participação é uma forma de investimento na atividade comum, transformando os participantes em pessoas interessadas no destino das suas atividades coletivas. A participação, portanto, foi também fonte do compromisso negro para com as suas irmandades.

A participação, contudo, não se limitava às atividades das irmandades negras. Pelo contrário: aquilo que frequentemente é identificado como a 'religiosidade da exterioridade' (BOSCHI, 1986, p.178-79) e que seria próprio da religiosidade barroca é uma religiosidade participativa. As grandiosas procissões só podiam ocorrer com a participação de muita gente. A participação não se limitava à integração do fiel à procissão, pois a própria produção de uma procissão envolvia muitas pessoas. Para se colocar uma procissão como o Triunfo Eucharistico na rua, ${ }^{1}$ por exemplo, teria sido necessário mobilizar uma legião de pessoas. Teriam sido necessárias pessoas para fazer as roupas usadas pelos figurantes, dos quais havia muitos, incluindo figuras míticas, dançarinos com roupas próprias, cristãos e mouros e muitos outros; alguém tinha que ter treinado as diversas configurações musicais que participariam do cortejo, que também eram muitos (entre eles os de 'suaves vozes e vários instrumentos'; os músicos dançantes; 0 
'Allemão com o clarim' entre muitos outros); precisavase de assistentes para preparar as alegorias que foram carregadas na procissão (os quatro ventos, os planetas entre outros); outras pessoas teriam que ter preparado os diversos andores dos santos das irmandades, tanto os andores dos oragos como os dos santos de devoção; teria sido também necessário organizar os membros das diversas irmandades e botar cada grupo no lugar que ocuparia durante a procissão. Sem dúvida, esse cortejo foi uma grande produção que mobilizou centenas de pessoas; mas vale lembrar que, além da procissão, a festa toda incluiu missas cantadas, um te-deum laudamus, touros, cavalhadas, comédias, saraus e festança geral na rua. Além do mais, a própria festa durou vários dias.

Esta foi apenas uma entre inúmeras festas que foram promovidas nas Minas no período colonial. Com efeito, o calendário anual nas vilas mineradoras era marcado por uma sucessão de mobilizações coletivas, em que se honravam os santos e datas importantes na vida da família real.

Esta contínua mobilização era propulsada, em grande parte, pela competição entre as irmandades, cada uma disposta a investir cada vez mais para promover a melhor festa da vila. As identidades coloniais, portanto, estavam fortemente associadas à irmandade (ou irmandades) a que pertenciam, sendo que o lugar de cada um na estru- tura social da época era marcado pela identidade forjada através do pertencimento a uma irmandade.

Mesmo com a decadência na produção de ouro, as populações dos antigos centros de mineração continuaram, na medida do possível, a sustentar um calendário barroco. Hoje a festa religiosa que agrega o maior número de pessoas é a Semana Santa. 0 fato de a Semana Santa ainda ser celebrada nos moldes do passado, indica que, em muitas comunidades, ainda existem pessoas dispostas a dar de seu tempo, seus talentos e seus recursos materiais para que ela se realize. Certamente, este empenho deriva das experiências promovidas pela participação em tais celebrações.

Embora muitas pessoas ainda estejam dispostas a contribuir para a produção da festa, as estruturas institucionais que a sustentam não são mais as mesmas do período colonial. As irmandades, as principais promotoras das festas, já não existem mais em muitas localidades, e mesmo onde elas ainda não foram totalmente desarticuladas, elas estão bem enfraquecidas em comparação com as irmandades coloniais e imperiais. Deste modo, a festa deixou de estar associada a irmandades para ser tornar um foco de identidade local. Hoje, em muitas antigas vilas mineradoras, a Semana Santa é uma festa da cidade e um símbolo do legado minerador do local. Este, pelo menos, é o caso na cidade sul-mineira da Campanha.

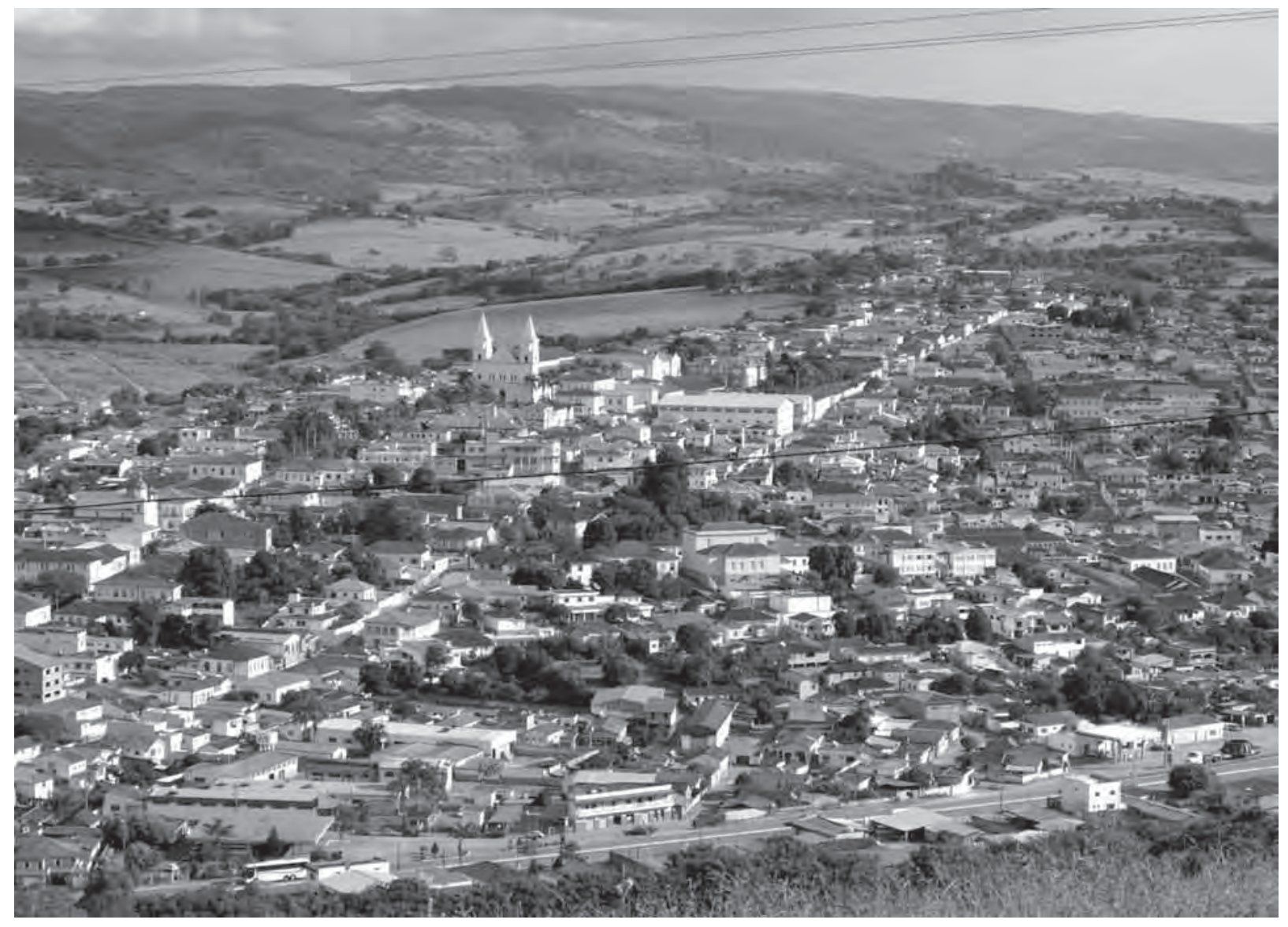

Ex.1 - Vista panorâmica de Campanha (MG), 2008 (Foto de Antonio M Ribeiro). 


\section{Campanha}

Campanha se estabeleceu originalmente como um povoado clandestino de mineradores, provavelmente nas primeiras décadas do século XVIII, mas o vilarejo só foi integrado judicialmente à colônia em 1737, quando foi 'descoberto' pelas autoridades que estavam ansiosos em recolher o 'quinto'. Quando os soldados chegaram no local, já havia ali uma população de aproximadamente dez mil pessoas, sendo 7,000 delas escravos negros a serviço da minoria branca, espalhada ao longo do Rio Verde, numa extensão de 20 léguas $^{2}$ (CASADEI E CASADEI, 1989, p.14).

Ao longo do século XVIII, o vilarejo foi se tornando o centro cultural e econômico da região, consolidando essa posição no século XIX quando se tornou um centro importante de abastecimento para o Rio de Janeiro. Como mostra o historiador Marcos Ferreira de ANDRADE (2005), o auge da Campanha foi o século XIX. As grandes fortunas de Campanha não derivaram do ouro, mas sim da pecuária e da agricultura. Assim, a 'cultura barroca' se desenvolveu em Campanha tardiamente, junto com o desenvolvimento econômico e o crescimento populacional. Um fenômeno que me parece significativo é que Campanha absorveu muitas pessoas que vieram dos centros de mineração após a queda na produção de ouro - e entre elas havia músicos.

Campanha recebeu um impulso econômico novo com a expansão cafeeira, mas acabou sofrendo com a crise agrária da década de 1960, e a partir de então, a economia local entrou num estado de estagnação. Muitos campanhenses deixaram a cidade para procurar oportunidades melhores nos centros econômicos mais dinâmicos, como São Paulo, Rio de Janeiro e Belo Horizonte. Hoje, muitos pés de café têm dado lugar às frutas cítricas, principalmente à mexerica-poncã. Ao lado da agricultura, que absorve mais de um terço da população, que hoje é de aproximadamente 14.000 pessoas, a cidade comporta algumas pequenas indústrias, a produção de artesanato, um pequeno comércio e diversas instituições ligadas à Igreja Católica.

\section{A Semana Santa em Campanha: uma pers- pectiva histórica}

Reconstruir a história da Semana Santa em Campanha é uma tarefa complexa, particularmente em relação ao século XVIII, dada a precariedade dos documentos que sobreviveram ao tempo na cidade. Mas, a partir do material existente, sabe-se que a Irmandade do Santíssimo Sacramento em Campanha teve seu compromisso autorizado em 1742. Embora a Irmandade tivesse pretensões de promover celebrações de Semana Santa com grandiosidade barroca, os recursos disponíveis limitavam os seus projetos. Isto fica evidente já no mais antigo termo referente à Semana Santa, que se encontra na página 126 do I Livro de Termos da Irmandade do Santíssimo Sacramento de Campanha:

Aos 7 de abril de mil setesentos e quarenta e oito em que se achou provedor, e mais irmãos abaixo assinados assentou em mesa em a qual foi proposto que como não chegarão as esmolas que particu- larmente se tinhão tirado pelos moradores dessa freguesia para se fazer Semana Santa suprisse a Irmandade como aquilo que faltasse para satisfação do quanto se dispender na dita Semana Santa e sendo proposto se determinou por mais votos que a Irmandade suprisse visto só o provedor da dita Irmandade ser de voto contrario, e declarou não consentir usar despesas da Irmandade, e em virtude do que se assentou nos assinamos, e eu Daniel Burga procurador da Irmandade que por ausencia do R.do escrivão João Rezende de Amorim fiz esse termo que assinei como escrivão.

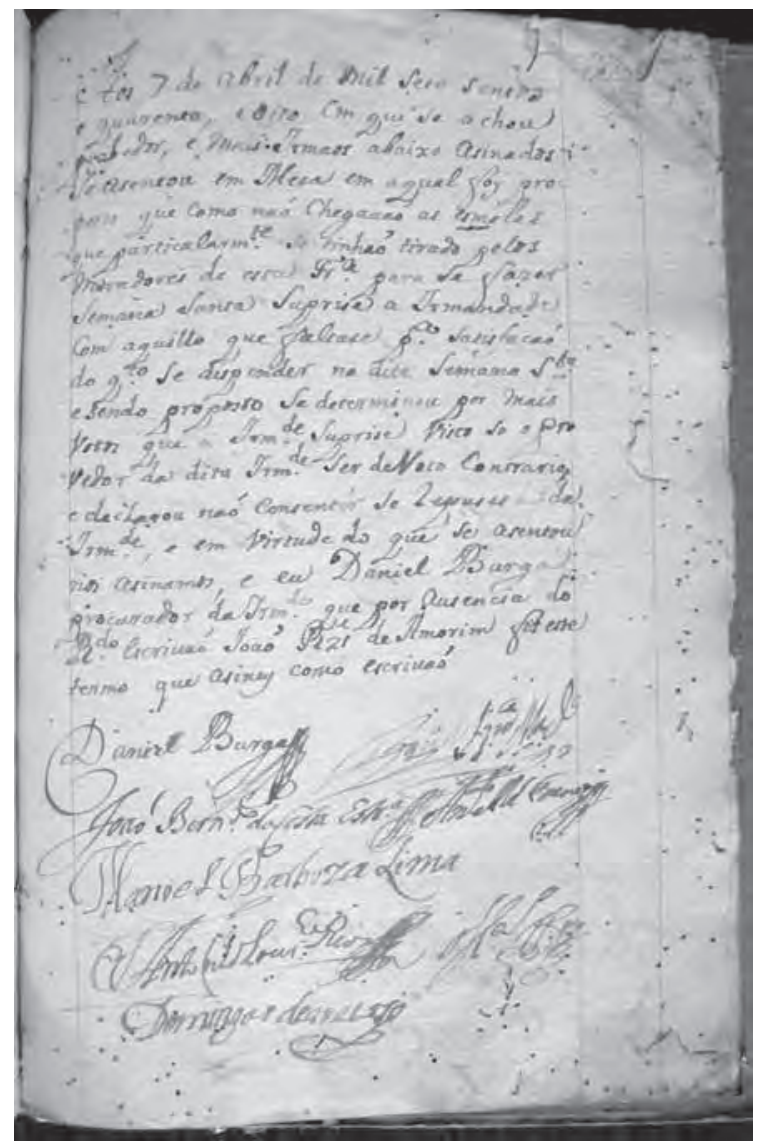

Ex.2 - Página 126 do I Livro de Termos da Irmandade do Santíssimo Sacramento de Campanha

(Foto de Antonio M Ribeiro).

0 termo não dá nenhuma indicação sobre como se celebrava a Semana Santa naquela época, mas claramente tinha custos, posto que a Irmandade precisaria suprir o que faltou das esmolas. A próxima vez que a Semana Santa é mencionada no Livro é num termo de 1760, quando a Irmandade se encontra em outra crise financeira, e ela se vê novamente na posição de ter que injetar fundos adicionais para promover uma festa. Mais uma vez, em 1776, a Irmandade está em dificuldades, pois arcou com despesas com a compra de ornamentos para a Matriz; assim, compromete-se a redobrar os esforços para angariar os fundos necessários junto à população. Curiosamente, é justamente em 1776 que há a primeira indicação do uso de 'tambores', isto é, escravos tocando caixas pelas ruas colhendo esmolas; esses escravos músicos podiam ser alugados de seus proprietários pelas irmandades para esse fim. Em Campanha, um certo Felipe Esteves Lima se apresentou à irmandade pedindo "meia livra de ouro" pelos serviços de seu tambor. 
Uma das principais despesas da festa era com música e estas despesas também indicam a presença de alguns músicos profissionais, embora, em Campanha, só há registros de sua presença a partir das últimas décadas do século XVIII. É improvável, contudo, que esses músicos pudessem sobreviver apenas com sua música. 0 mais provável é que a música servia como complemento financeiro para a grande maioria de músicos na cidade, cujas atividades financeiras principais estavam em outras áreas $^{3}$ - até porque alguns músicos tinham que esperar vários anos antes de receber pelos seus serviços. Este é caso do primeiro músico cujo nome é fornecido no livro de despesas da Irmandade do Santíssimo Sacramento. Em 1795, um certo Luciano da Cunha Serrão, que era natural de Vila Rica (LEFORT, 1976, p.3), recebeu "dezessete oitavas e meia e cinco vinténs de ouro que [Ihe] era devedora a Irmandade do Santíssimo Sacramento da assistência que [fez] com a [sua] música no jubileu de Quinta-feira santa no ano de 1790."

A partir do início do século XIX, Campanha começa a ter uma vida cultural cada vez mais intensa. Esta efervescência fica particularmente evidente na descrição feita numa carta da Câmara de Campanha para o Ministro do Imperador e Presidente da Província relatando as comemorações que se fez na vila quando da declaração da independência do Brasil em 1822. Para a ocasião, os campanhenses demonstraram "as devidas graças ao Fundador do Império" com um Te Deum, "acompanhado por ... excellente musica a dois coros, ... regida pelo Reverendo Vigario João Dias". Houve ainda rica procissão à noite seguida de "um espendido chá", onde "tocarão-se muitos bons concertos de Musica, e excellentes sonatas de Piano, ... [seguidos por] Contradansas optimamente executadas pelas principaes Senhoras, [e também] Valsarão outros entremedios, e assim alternativamente prosseguiu o baile." (VALLADÃO, 1940, p.56) Houve ainda alvorada no dia seguinte, culminando os festejos com "a Opera, ... offerecida ... pelos Estudantes de Grammatica Latina" (VALLADÃO, p.57). Durante toda a madrugada, houve também música nas ruas, executada por seresteiros com suas violas, guitarras e pandeiros (VALLADÃO, p.59).

É também no século XIX que o calendário de festas religiosas se consolida e a estrutura de cada uma vai se definindo, com diferentes grupos de músicos tomando a frente das diversas configurações festivas. Já em meados do século XIX, a Semana Santa campanhense inclui atividades ao longo da semana - e essa estrutura persiste com apenas algumas alterações até hoje:

$\begin{array}{ll}\text { Domingo de Ramos } & \begin{array}{l}\text { Procissão de Ramos e Procissão do } \\ \text { Triunfo }\end{array} \\ \begin{array}{l}\text { Segunda-feira } \\ \text { Terça-feira } \\ \text { dos Passos }\end{array} & \begin{array}{l}\text { Procissão do Depósito } \\ \text { Puarta-feira }\end{array} \\ \text { Quinta-feira } & \text { Procissão do Encontro ou Procissão } \\ & \text { Lava-pés e Ofício de Trevas }\end{array}$

Sexta-feira da Paixão Descimento da Cruz e Procissão do Enterro

Domingo

Procissão da Ressurreição e Coroação de Nossa Senhora

Cada uma dessas celebrações era acompanhada de rituais específicos e músicas próprias. Os músicos envolvidos na Semana Santa, portanto, tinham um repertório grande para aprender e um horário intenso para cumprir.

Em algum momento do último quartel do século $\mathrm{XIX}$, a Irmandade do Santíssimo deixou de existir devido às investidas da Igreja para limitar o controle das irmandades, um processo frequentemente chamado de 'romanização'. Com a dissolução das irmandades, as festas passaram a ser organizadas por comissões eleitas anualmente para este fim e, assim, sua continuidade passou a depender dos esforços das comissões e do interesse dos devotos. Deste modo, houve a decadência de muitas festas e a população passou a se concentrar em algumas celebrações, um processo que se repetiu em diversas localidades de Minas. ${ }^{4}$ Em Campanha, como em muitas cidades históricas, os esforços da população foram direcionados para a Semana Santa e a Festa do Rosário, além de algumas festas menores ligadas às especificidades da localidade.

As duas principais fontes para documentar o desenvolvimento da Semana Santa em Campanha a partir do último quartel do século XIX são os jornais locais e os manuscritos musicais que sobreviveram ao tempo. Os manuscritos mais antigos de peças coloniais encontrados em Campanha datam de meados do século XIX em diante. Estes manuscritos se encontram hoje no Museu da Inconfidência em Ouro Preto e na Biblioteca de Música da USP. Há também alguns exemplos colhidos em Campanha na coleção Francisco Curt Lange, que também se encontra no Museu da Inconfidência. Estas coleções contém numerosas cópias de obras de alguns dos principais compositores coloniais mineiros, como Manuel Dias de Oliveira (São José del Rey, c.1735-1813), José Joaquim Emerico Lobo de Mesquita (Serro, 1746-1805), Jerônimo de Souza Lobo (Ouro Preto, f. c. 1803), João de Deus de Castro Lobo (Ouro Preto e Mariana, 1794-1832) entre outros, mas também inclui obras de músicos do século XIX cujas atividades se concentravam em Campanha, como Carlos Moura (f. 1889) e José Luiz Pompeu da Silva (1852-1924).

Através dos jornais podemos notar o surgimento de tempos em tempos de uma nova configuração de músicos assumindo as performances para as celebrações da Semana Santa, mas a partir do final do século também começam a surgir indicações do repertório a ser apresentado. Por exemplo, em 1896, a música da Semana Santa foi dirigida por José Luiz Pompeu da Silva e, de acordo com o regente, o repertório incluiria obras de Jeronimo de Souza [Lobo], Padre José Maurício [Nunes Garcia], Padre João de Deus [de Castro Lobo], Marcos [Antônio Fonseca] Portugal e Francisco Manuel da Silva (Monitor Sul Mineiro, 22/03/1896:2). Já em 1899, a Banda Giulieta Dionesi, 


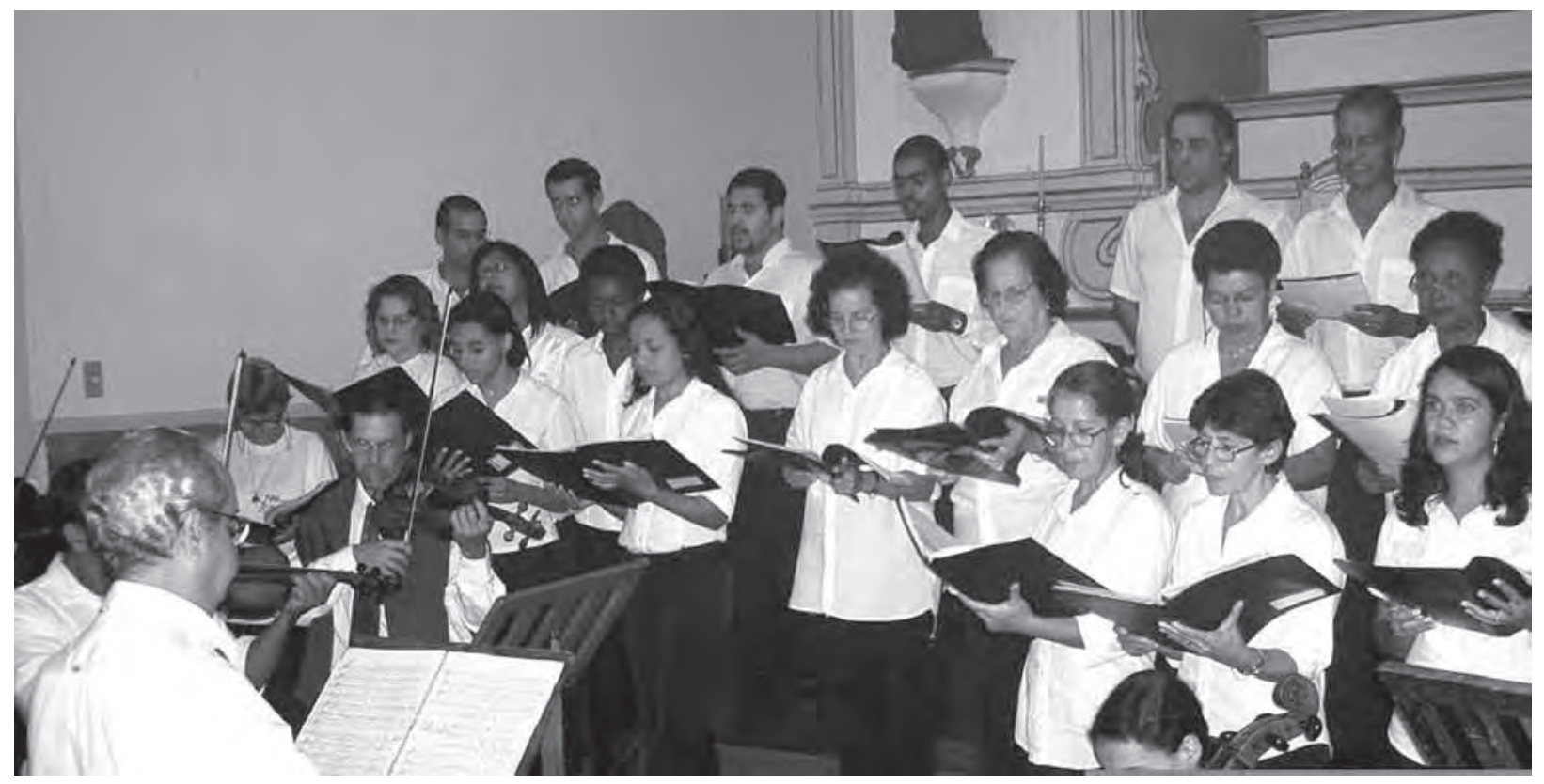

Ex.3 - Coral Campanhense, 1960 (Foto do Arquivo do Coral Campanhense).

dirigida por Antonio Faustino de Figueiredo Brasil (f.c. 1901) e Zoroastro Pamplona de Azevedo (c. 1874-1920), assumiu a responsabilidade pela festa, apresentando música de João Jordani, Giuseppe Ceruti, Jeronimo de Souza Lobo e Manoel Dias de Oliveira.

A grande novidade da Semana Santa em 1940 foi a integração da obra de João Baptista Lehmann (1873-1955). A sua obra, especialmente aquela contida na Harpa de Sião, tornou-se muito popular em Minas e ainda pode ser ouvida em muitas localidades mineiras até hoje. Inclusive, ainda faz parte de algumas cerimônias da Semana Santa de Campanha.

A partir de evidências como estas, pode-se perceber alguns dos processos envolvidos na escolha do repertório usado na Semana Santa de Campanha e sua influência na consolidação do repertório atual.

\section{0 repertório atual}

Em Campanha hoje, as peças mais valorizadas do repertório da Semana Santa são os Motetos de Passos e os Motetos de Dores cantados nas procissões de terça e quartafeira, respectivamente. Estas obras foram compostas por Manoel Dias de Oliveira, sendo que sua performance difere muito do que provavelmente tenha sido a intenção original do compositor. Os campanhenses conhecem os sete Motetos de Passos, mas eles são cantados por apenas um coro em vez dos dois previstos originalmente; os compassos em branco do primeiro coro, onde o segundo coro estaria cantando, foram simplesmente suprimidos. A instrumentação também foi alterada, sendo que as flautas da versão original foram substituídas por violinos, e as trompas foram cortadas. Os Motetos de Dores sofreram ainda maiores modificações: além de terem sido reduzidos a três motetos apenas (sendo que a série é composta de quatro motetos), todos os três são executados com uma introdução instrumental que não constava dos originais; essas introduções foram colocadas, provavelmente, no século XIX, pois se achava que as coisas da Nossa Senhora tinham que ser embelezadas para agradar a santa. As cópias campanhenses mais antigas dos motetos com uma data clara foram copiadas em 1885 e pertenciam a um certo Tristão Coelho Netto (c.1830-1902). Nestas cópias as introduções instrumentais já estão presentes. Como ainda não foram encontradas cópias destas peças feitas em outras cidades que incluam as introduções, é possivel que elas tenham sido compostas em Campanha mesmo, talvez até por Tristão Coelho Neto, posto que todas as cópias destas obras do século XIX ainda existentes foram copiadas por ele.

Existe uma cópia dos Motetos de Dores feita por Marcelo Pompeu em 1905 que é particularmente interessante: 1) a cópia tem formato de partitura completa, que é muito raro em Minas, e 2) esta partitura indica o que será suprido para eliminar o segundo coro. É possível que estas marcações a lápis teriam sido feitas na década de 1950 para acomodar as competências musicais de cantores amadores do coral que se formou naquela época, pois alguns músicos da cidade identificaram as marcações como tendo sido feitas por Maria Ilza Musa Pompeu (1915-2005) ${ }^{5}$, a ensaiadora do coral naquela época.

Além dos motetos, o repertório para as celebrações da Semana Santa em Campanha inclui outras peças de Manuel Dias de Oliveira: um Miserere cantado na Procissão do Depósito na segunda-feira à noite e na Pro- 
cissão do Encontro; Pupili, que é cantado na Procissão do Enterro da Sexta-feira Santa; e Surrexit Dominus Vere, cantado na Procissão da Ressurreição no domingo de manhã. Canta-se também um Tractus de Joaquim José Emerico Lobo de Mesquita que foi adaptado nos anos de 1960 por Maria Ilza Musa Pompeu a partir de uma partitura que Ihe foi dada por Francisco Curt Lange numa de suas visitas a Campanha. E canta-se várias outras peças coloniais, cujos compositores ainda não foram identificados, como 0 Redemptor, cantado na quinta de manhã durante a benção dos Santos Óleos. E como vimos, peças de João Batista Lehmen também ainda constam do repertório.

\section{0 coral campanhense}

Entrando na década de 1950, os organizadores da Semana Santa começaram a ter dificuldades em recrutar cantores para as festividades e por isto, em 1958 o pároco de então, Mons. João Rabelo de Mesquita, convocou um grupo de jovens para formar um coral que teria a responsabilidade de aprender um repertório apropriado para que não fosse mais necessário sair à procura de voluntários a cada ano, 0 que estava comprometendo a qualidade das performances nas celebrações. E assim surgiu o Coral Campanhense, que existe até hoje, tendo, como sua principal função, proporcionar a música da Semana Santa, embora também can- te para outras funções, particularmente casamentos, mas também encontros de corais e recitais eventuais.

Como foi fundado para a Semana Santa, logo em 1958 o coral começou a aprender o repertório que cantaria para estas cerimônias. Entre os primeiros membros, eram poucos os que sabiam ler música e por isto os motetos, que estavam entre as primeiras peças a serem aprendidas, foram simplificados. Todos os membros do coral receberam partituras, mas elas eram - e continuam sendo - usadas como auxílio à memória e para os cantores se certificarem dos textos das peças. Aos poucos o coral foi ampliando o seu repertório e esta música passou a ser cantada ano após ano na Semana Santa.

\section{A banda}

Além da música vocal, as festividades barrocas sempre incluíam conjuntos de sopro nas procissões. Durante o século XVIII e boa parte do século XIX, a procissão caminhava com acompanhamento de charamelas, trompas e caixas. Em meados do século XIX, criou-se a válvula, que permitiu a construção de instrumentos de sopro que não eram apenas mais fáceis de tocar; eram também mais fáceis de afinar. Começou-se então a produção em massa desses instrumentos e as bandas de música, matizadas nas bandas militares, começaram a se propagar pelo país.

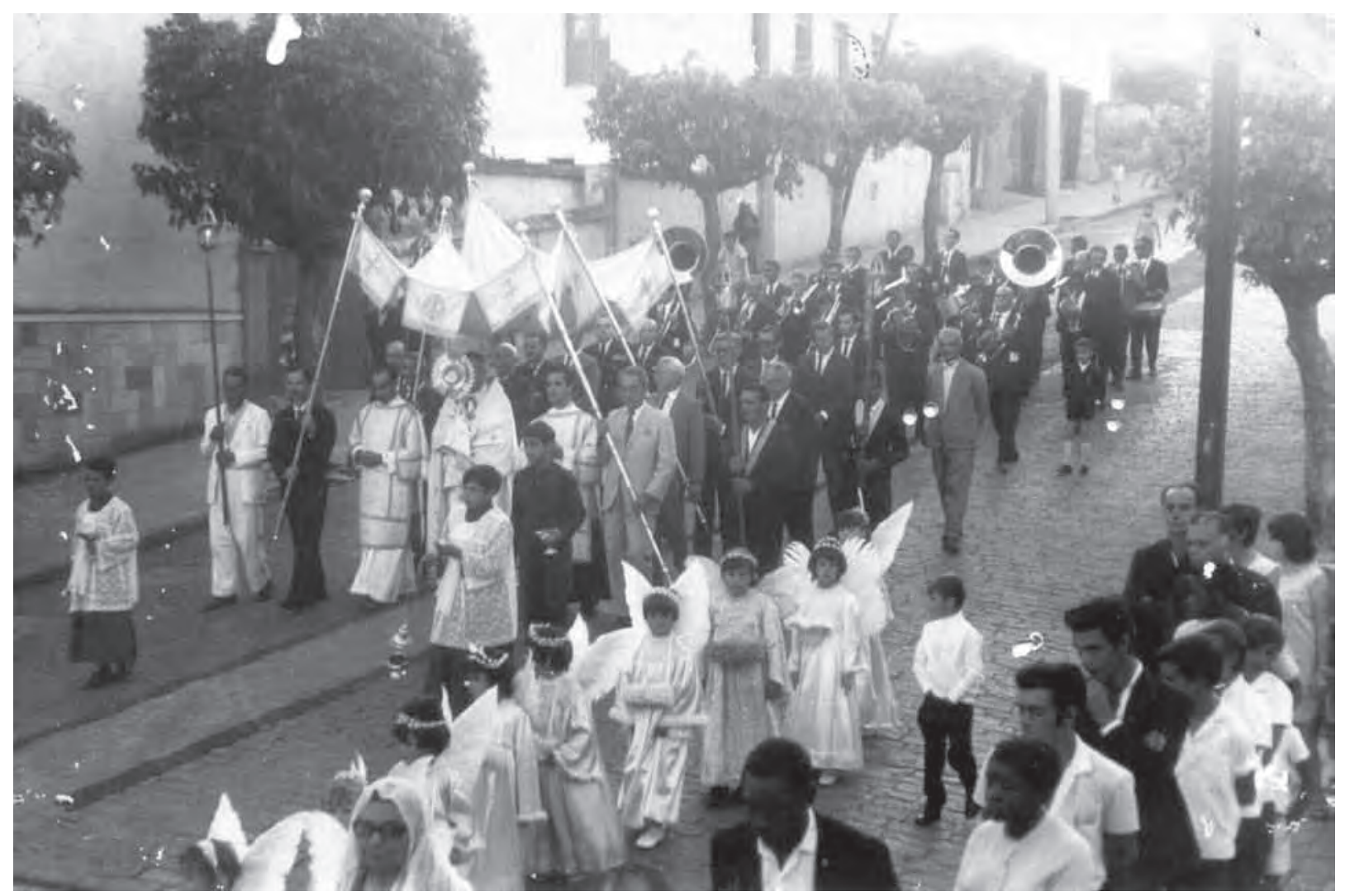

Ex.4 - Banda Dom Ferão acompanha uma procissão, década de 1950 (Foto de Paulino Araújo). 


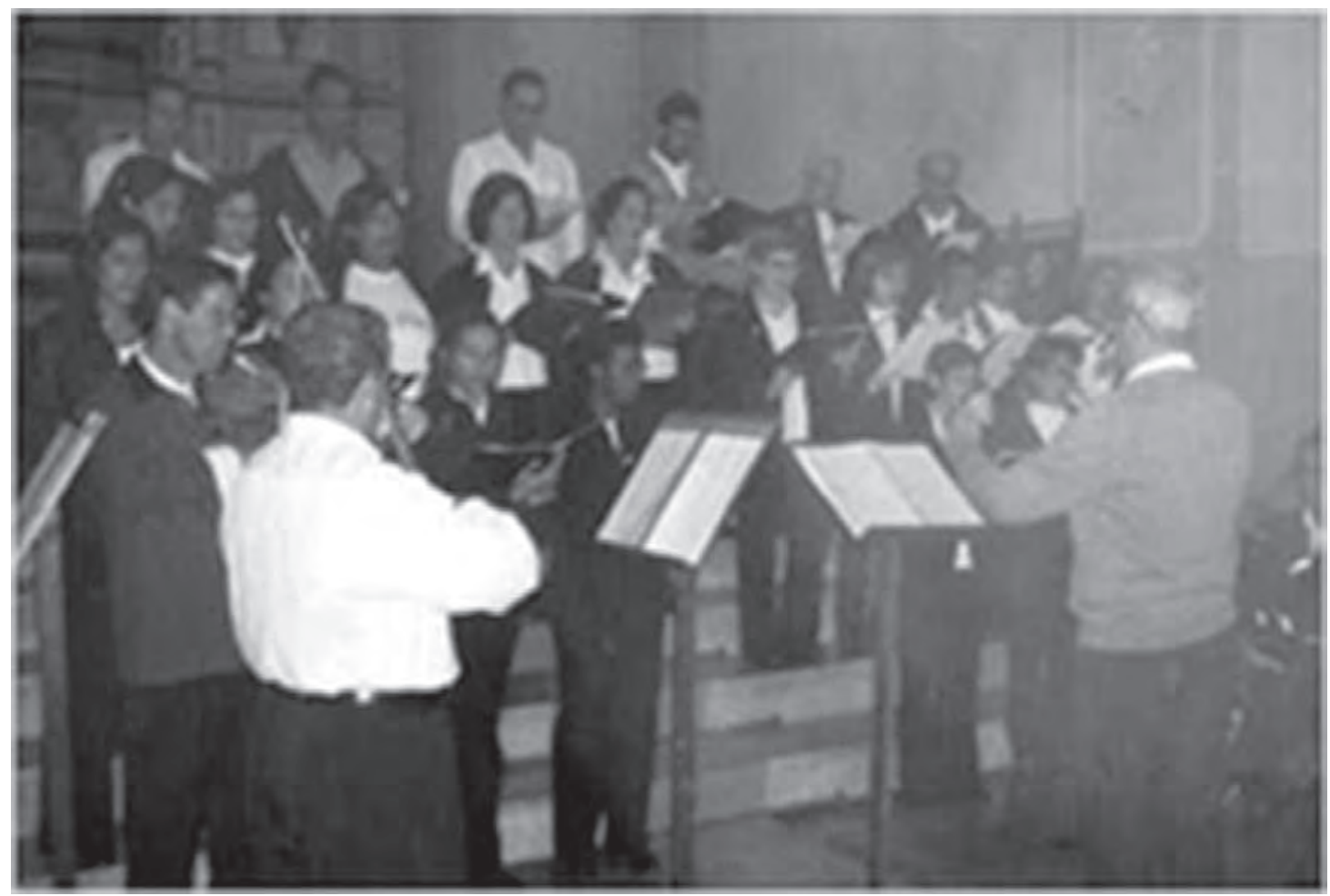

Ex.5 - Coral campanhense canta um moteto na Catedral Santo Antonio, 2002 (Foto de Maira Reis Ribeiro).

Em Minas, onde havia um contexto pronto para estes conjuntos, a apropriação do novo instrumental foi relativamente rápida. Em Campanha, a primeira banda, a 'Corporação Musical Giulietta Dionesi', dirigida por Antônio Faustino Figueiredo Brazil, foi fundada em 1887. Ela se tornou a 'Banda Concórdia' quando foi assumida por Zoroatro Pamplona de Azevedo (1874-1920), após a morte de Antônio Faustino em 1901. Uma segunda banda, a 'Dom Pedro II', uma banda de negros sob a direção de José e Olvídio Grilo, foi fundada na virada do século. No entanto, em suas memórias, Hildegardo Moraes (1935) relata que se lembra da velha banda de sopro que tocava apenas na Semana Santa, sendo ela composta de trombone de vara (Bernado Meirinho), clarinete (Constantino) e trombone (Tristão Coelho, Augusto Azevedo, Antão Trant), entre outros.

A principal função das bandas em Campanha no decorrer do século 20 foi a de liderar as procissões religiosas e tocar para as festividades cívicas da cidade. A relação entre a banda e a Semana Santa, contudo, é bastante estreita, pois os membros novos começam o seu aprendizado com as marchas fúnebres tocadas nas procissões de segunda, terça, quarta e sexta-feira durante a Semana Santa. Os jovens são recrutados logo após a Semana Santa, e passam seu primeiro ano estudando as doze marchas fúnebres do repertório local. A partir do segundo e terceiro anos, passam a estudar os dobrados que precisarão tocar nas demais procissões religiosas e os hinos que são tocados nos eventos cívicos. ${ }^{6}$

\section{A Semana Santa e a experiência barroca}

A Semana Santa campanhense poderia ser compreendida como um grande drama coletivo, composto por uma série de celebrações e, com cada celebração, há um crescendo ritual, cuja intensificação, ao longo da semana, vai promovendo uma 'experiência barroca' entre os devotos através do impacto sensorial que provoca. Não é possivel descrever esse processo de forma extensa, mas vale ressaltar alguns momentos particularmente eficazes, que são considerados os mais marcantes da Semana pela própria população campanhense.

0 primeiro ritual de grande impacto ocorre na segundafeira à noite com a Procissão do Depósito. Já está escuro e a população se encontra na frente da catedral. Logo, sai da Igreja um enorme andor contendo a imagem de Nosso Senhor dos Passos. A banda se posiciona atrás do andor e inicia uma marcha fúnebre, tocada de forma tão lenta que mal dá para os devotos caminharem no seu andamento. Uma atmosfera de extrema solenidade se instaura imediatamente e o povo segue a banda para a Igreja das Dores onde a imagem será 'depositada' em preparação para a Procissão dos Passos no dia seguinte. Quando a procissão chega na Igreja das Dores, as portas estão fechadas. Primeiramente há um sermão realçando o sacrifício de Cristo pela humanidade - suas dores e paixão detalhadamente descritas - promovendo sentimentos de empatia profunda entre os fiéis. No final do sermão, as portas da igreja se abrem e ali está o coral, que inicia o canto do Miserere de 
Manoel Dias, aumentando ainda mais os sentimentos de piedade, respeito e compaixão dos devotos.

Outro momento aguardado ansiosamente pelos devotos campanhenses ocorre na terça-feira durante a Procissão do Encontro, em que as imagens de Nossa Senhora das Dores e de Nosso Senhor dos Passos se encontram. No momento do encontro, ouve-se novamente o Miserere, seguido do Terceiro Moteto de Passos, Exeamus, cujo texto: Exeamus ergo ad eum extra castra, improperium ejus portantes, significa "Saimos, portanto, ao seu encontro fora do acampamento, carregando a sua humiIhação." Muitas pessoas me falaram que sempre choram neste momento, sentindo a dor de Maria, que teria que testemunhar a morte do filho.

Na quarta-feira, ocorre a Procissão de Dores, em que o coral canta os Motetos de Dores diante dos Passos. Antigamente essa procissão era seguida pelo Ofício de Trevas, uma cerimônia complexa - mas extremamente emotiva - que a Igreja supriu. ${ }^{7}$

0 evento mais marcante da Semana Santa ocorre na Sexta-Feira da Paixão, começando com o Descimento da Cruz. 0 drama da morte de Cristo é apresentado aos fiéis de forma viva. Uma senhora me disse o seguinte: "0 Descimento é o momento mais triste da Semana Santa aqui. A gente vê Jesus lá na cruz - como ele sofreu, Meu Deus! Aí eles tiram a coroa de espinhos, tiram os cravos - aquele braço vai descendo - o outro - e a mãe do lado. Todo ano eu choro". Uma vez no esquife, ouve-se a primeira performance do Canto de Verônica, que parece um choro, com o texto: 0 vos omnes qui transitis per viam, attendite et videre si est dolor sicut dolor meus (A vós todos que passais pelo caminho, olhai e vede se há dor semelhante à minha).

No Domingo de manhã, contudo, o ambiente muda totalmente, com a Procissão da Ressurreição, que começa às 5 da manhã. 0 coro canta Surrexit, também de Manoel Dias, e a banda passa a tocar dobrados. Os sinos da igreja tocam novamente e um ar festivo passa a dominar a cidade. Como não poderia deixar de ser, o coral termina suas responsabilidades musicais com 0 Alleluia de Haendel.

\section{Conclusões}

As celebrações da Semana Santa são estruturadas para causar um grande impacto emocional nos devotos. Ano após ano, o grande drama da morte e ressurreição de Cristo é encenada e, a cada ano, as fortes emoções se renovam com mais uma encenação coletiva. A encenação envolve muita gente: há os grupos musicais, principalmente o coral e a banda, mas também os instrumentistas que acompanham o coral e os tocadores da matraca que perambulam pela cidade ao longo da Semana Santa; há os figurantes das procissões e cerimônias diversas da Semana, como os apóstolos, que participam de muitas celebrações com roupas próprias, mas também os figurantes da encenação da paixão de Cristo na Sexta-feira Santa;

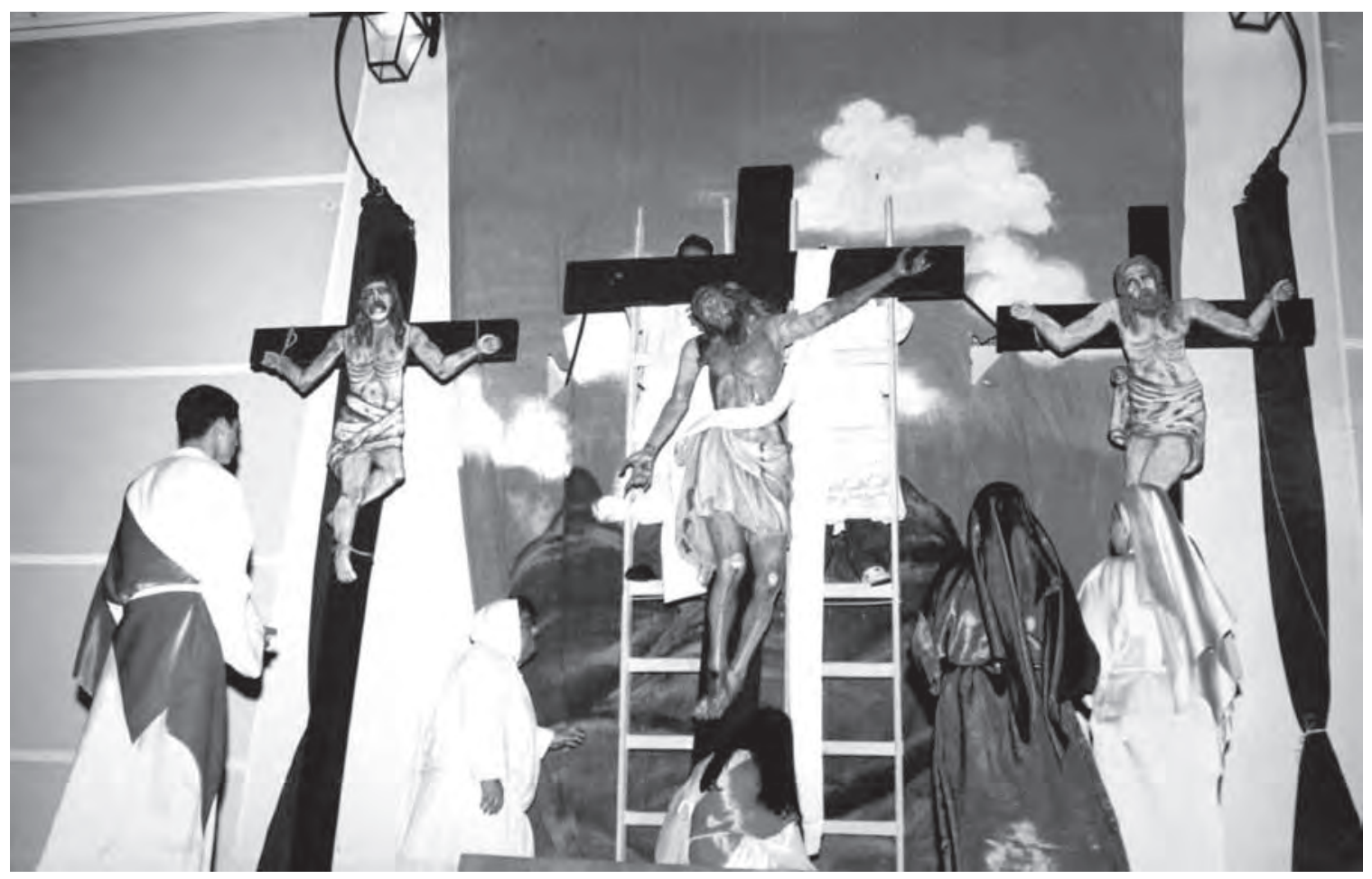

Ex.6 - Descimento da Cruz, 2003 (Foto de Almir Ferreira Lopes). 
e há pessoas para diversas tarefas associadas à Semana Santa, como as pessoas que preparam os andores, as que preparam as igrejas para os diversos eventos, as que armam o palanque para o Descimento, as que preparam os ambientes para os sermões, as que preparam os passos, as que carregam os andores; e a polícia também tem de ser mobilizada para preparar as ruas e garantir que os carros não estacionem no trajeto da procissão. Ao longo da Semana Santa, uma porcentagem significativa da população de Campanha se mobiliza para a grande dramatização comunitária. Os músicos talvez tenham o horário mais intenso, embora hoje ele não seja mais tão intenso quanto foi há algumas décadas.

Como vimos, no passado, este investimento de tempo, talento e recursos materiais era feito em prol da irmandade, uma instituição que já não existe mais em Campanha. Hoje a Semana Santa é oficialmente entendida como uma celebração da paróquia, mas informalmente ela é vista como uma festa da cidade. É a população de Campanha que se mobiliza para promover a festa e reviver seu drama. Para isto, os devotos fazem um grande investimento, oferencendo seu tempo, seus talentos e suas esmolas para o bom andamento da festa.

A Semana Santa de Campanha adquiriu uma estrutura fixa, não só em termos dos rituais, que são determinados pela Igreja, mas em termos dos elementos expressivos usados nela: de um ano para o outro, as mesmas imagens saem em procissão; o Descimento ocorre do mesmo jeito, com as mesmas figuras vestidas com as mesmas roupas; os mesmos motetos são cantados nos mesmo lugares, diante dos mesmos passos. Existem peças musicais específicas para cada ritual da Semana Santa e, entra ano, sai ano, elas são cantadas da mesma forma nestes momentos. Até a banda já tem uma sequência fixa para as marchas fúnebres, cada uma adaptada às especificidades do trajeto da procissão. ${ }^{8}$ A Semana Santa de Campanha, então, é efetivamente a Semana Santa de Campanha. Ela efetivamente se 'localizou' na cidade. Ela é produzida pela comunidade, para a comunidade, e os moradores da cidade conhecem o enredo da dramatização e revivem suas emoções a cada nova encenação.

Quem faz um investimento, geralmente também se sente dono (ou dona) daquilo em que investiu. 0 ato de investir promove um sentimento de compromisso com o investimento. Em Campanha o investimento que a comunidade faz na festa faz com que ela se sinta dona dela. 0 fato de que as festividades promovem fortes emoções aumenta ainda mais o sentimento de pertencimento - e a grandeza da produção contribui para os sentimentos de orgulho que a comunidade tem com a festa. Trata-se de um orgulho que deriva do poder de produzir um evento tão 'maravilhoso'!

A literatura sobre a estética barroca tende a enfatizar o uso dela pelas estruturas de poder, posto que, através da grandiosidade e do excesso, os poderosos podiam ostentar seu poderio. Sem dúvida, o barroco foi usado como forma de violence douce (BOURDIEU, 2007), tanto na Europa como no mundo colonial. No entanto, o potencial de empoderamento inerente à estética barroca não se restringe às elites. Como vemos atualmente em muitas cidades históricas de Minas Gerais, ela também pode ser mobilizada por devotos comuns e comunidades periféricas. A sensibilidade barroca é construída através da participação e da integração do fiel ao rito e ela vem sendo reproduzida ao longo dos séculos em Minas Gerais justamente por causa dos sentimentos de empoderamento que ela traz. A força das tradições musicais nas cidades históricas de Minas deve muito ao poder da experiência da maravilha. 


\section{Referências}

ANDRADE, Marcos Ferreira de. Família, fortuna e poder no império do Brasil: Minas Gerais, Campanha da Princesa (17991850). Tese de doutorado, Universidade Federal Fluminense, 2005.

BORGES, Célia Maia. Escravos e libertos nas irmandades do rosário: devoção e solidariedade em Minas Gerais - séculos XVIII-XIX. Juiz de Fora: Editora da UFJF, 2005.

BOSCHI, Caio César. Os leigos e o poder: irmandades leigas e política colonizadora em Minas Gerais. São Paulo: Átiсa, 1986 .

BOURDIEU, Pierre. Esboço de uma teoria da prática. Precedido de três estudos de etnologia Kabila. Oeiras: Celta, [1972] 2002

A Distinção: crítica social do julgamento, Porto Alegre, Editora Zouk, [1979] 2007.

CASADEI, Thalita de Oliveira, e CASADEI, Antonio. Aspectos históricos da cidade da Campanha. Petrópolis: Editora Gráfica Jornal da Cidade, 1989

MELLO E SOUSA, Marina. Paraty: a cidade e as festas. Rio de Janeiro: Ouro sobre Azul, 2008.

MORAES, Hildegardo. Reminiscencias da Campanha. Minas do Sul, Anno 1, no. 3:2, 1935.

REIS, João José. A morte é uma festa: ritos fúnebres e revolta popular no Brasil do século XIX. São Paulo: Companhia das Letras, 1991.

SALLES, Fritz Teixeira de. Associações religiosas no ciclo do ouro: introdução ao estudo do comportamento social das irmandades de Minas no século XIII. São Paulo: Perspepectiva, 2007 [1963].

SKRINE, Peter N. The Baroque: Literature and Culture in Seventeenth-Century Europe. Cambridge: Methuen \& Co, 1978. STOCKSTAD, Marilyn. Art History. Saddle River: Prentice Hall, 2002.

LEFORT, José do Patrocínio. Músicos da Campanha. Campanha: Voz diocesana, No. 915, Ano 29:3, 1976.

VALLADÃO, Alfredo. Campanha da Princesa, Volume 2 (1821-1909). Rio de Janeiro: Leuzinger, 1940.

TONI, Flávia Camargo. A música nas Irmandades da Vila de São José e o Capitão Manoel Dias de Oliveira. Dissertação de mestrado, University of São Paulo, 1985.

Notas

10 Triunfo Eucharistico foi uma grande procissão que ocorreu em Vila Rica em 1733 por ocasião do translado do Santíssimo Sacramento da Igreja de Nossa Senhora do Rosário para a Matriz de Vila Rica, a Igreja de Nossa Senhora do Pilar, após trabalhos de restauro na Matriz. Os festejos do evento foram documentados detalhadamente por um certo Simão Ferreira Machado.

2 Uma légua equivale a seis quilômetros. Logo, a comunidade ocupava uma extensão de aproximadamente 120 quilômetros. Tratava-se, portanto, de um povoado bastante disperso.

3 Esta situação se assemelha à de São José del Rei, descrita por Flávia Toni (1985).

4 Este processo também foi comum a outras regiões do país com fortes legados coloniais, como Paraty, RJ (MELLO E SOUZA, 2008).

5 Maria Ilza Musa Pompeu vinha de uma família de músicos, que incluiu seu avô, José Luiz Pompeu da Silva, seu pai, Marcello Pompeu (1885-1988), seu tio, Samuel Pompeu, e seus irmãos, Lucilia (piano), José Luiz (violoncelo), Marcelo Filho (violino).

6 Nos últimos cinco anos, com a popularização dos 'encontros de bandas', um novo repertório 'popular' está começando a dominar a atenção da banda de Campanha, mas seu papel cívico e religioso continua sendo a justificativa dada pela prefeitura pelo seu apoio ao conjunto. É possível, contudo, que a relação entre a banda e a Semana Santa comece a enfraquecer, particularmente se o repertório inicial dos novos membros não mais se centrar nas marchas fúnebres.

7 Esta cerimônia começa com as quinze velas do candelabro acesas. Elas vão sendo apagadas uma a uma, deixando apenas uma acesa. Esta vela é escondida, deixando a igreja escura. 0 povo começa a fazer barulho, indicando o caos no mundo com a morte de Jesus. A vela acesa é retirada do seu esconderijo, indicando a ressurreição e o retorno da ordem. Em algumas cidades mineiras o Ofício das Trevas é ainda celebrado, sendo fonte de muito orgulho para elas.

8 Por exemplo, há marchas mais curtas que são reservadas para aqueles trechos em que o espaço entre um passo e outro é mais curto; toca-se marchas em registros confortáveis nos trechos com subidas; marchas associadas a certos membros da banda são tocadas quando o conjunto passa diante de sua casa, e assim por diante.

Suzel Ana Reily concluiu seu Doutorado em Antropologia Social em 1990 na Universidade de São Paulo e desde então trabalha como docente na Queen's University Belfast. Presidiu o Forum Britânico de Etnomusicologia (British Forum for Ethnomusicology) entre 2000-2003 e o Conselho da Sociedade de Etnomusicologia (2003-2005). Atuou como co-editora do British Journal for Ethnomusicology (1998-2001) e desde 2003 é editora de resenhas de sites eletrônicos para o Yearbook of Traditional Music. Suas poblicações incluem Voices of the Magi (Chicago 2002) e a organização de Brazilian Musics, Brazilian Identities (BJE 2000) e The Musical Human: Rethinking John Blacking's Ethnomusicology in the $21^{\text {st }}$ Century. Atualmente está finalizando uma monografia enfocando a vida musical de Campanha. 